\title{
A!
}

This is an electronic reprint of the original article.

This reprint may differ from the original in pagination and typographic detail.

Buiskikh, Dmitry; Zakeri, Behnam; Syri, Sanna; Kauranen, Pertti

\section{Economic feasibility of flow batteries in grid-scale applications}

Published in:

15th International Conference on the European Energy Market, EEM 2018

DOI:

10.1109/EEM.2018.8470012

Published: 20/09/2018

Document Version

Peer reviewed version

Published under the following license:

Unspecified

Please cite the original version:

Buiskikh, D., Zakeri, B., Syri, S., \& Kauranen, P. (2018). Economic feasibility of flow batteries in grid-scale applications. In 15th International Conference on the European Energy Market, EEM 2018 (Vol. 2018-June). [8470012] IEEE. https://doi.org/10.1109/EEM.2018.8470012

This material is protected by copyright and other intellectual property rights, and duplication or sale of all or part of any of the repository collections is not permitted, except that material may be duplicated by you for your research use or educational purposes in electronic or print form. You must obtain permission for any other use. Electronic or print copies may not be offered, whether for sale or otherwise to anyone who is not an authorised user. 


\section{Economic feasibility of flow batteries in grid-scale applications}

\author{
Dmitry Buiskikh, Behnam Zakeri, Sanna Syri \\ Department of Mechanical Engineering \\ Aalto University, School of Engineering \\ FIN-00076, Espoo, Finland \\ dmitry.buiskikh@aalto.fi
}

\author{
Pertti Kauranen \\ Department of Chemistry and Materials Science \\ Aalto University, School of Chemical Engineering \\ FIN-00076, Espoo, Finland
}

\begin{abstract}
Due to their properties, the most suitable application for flow batteries currently is a bulk energy storage. This paper investigates the economic feasibility of the technology in terms of monetary profitability in the appropriate business cases, namely employment in energy markets and in isolated island systems with the high share of renewable generation. We calculate the flow batteries life cycle costs and compare them with the potential revenues from participation in the Finnish energy markets and operation in isolated power systems of the Faroe Islands and the island of Graciosa. We find that the flow batteries exploitation in the Finnish market is not profitable - they collect $43-60 \%$ of their costs in the most promising application. The island cases represent a more viable option due to the high fuel costs of the thermal plants that the batteries and renewable sources substitute or decrease their share. However, the revenue and subsequent profitability highly depend on the volatile fuel prices.
\end{abstract}

Index Terms: Cost-benefit analysis, Energy storage, Flow batteries

\section{INTRODUCTION}

Electrical energy cannot be stored. It is generated and consumed simultaneously [1]. Meanwhile electrical energy consumption is often not synchronous with its production. The issue has been turning more apparent with the constantly rising share of variable renewable energy sources (RES) in the generation. Meanwhile any supply failure is associated with high costs [2].

The challenge could be overcome with the help of the "energy storage" (ES), or "electrical energy storage" (EES) systems. Pumped hydro energy storage (PHES), that transforms electrical energy into mechanical form, overwhelmingly dominates worldwide in the numbers of installed capacity (184 GW, or $94 \%$ of the total amount) [3]. However, the technology has significant geographical requirements and restrictions [4].

Electrochemical batteries, or battery energy storage systems (BESS), are more versatile and flexible than PHES and could be employed in wider range of conditions. Among BESS, the majority among the utility-scale applications belongs to Lithium-ion ( $\mathrm{Li}-\mathrm{ion})$ batteries $(59 \%$ of the total installed capacity [5]). The technology is prominent for the high efficiency (90\%) and energy density (75-200 Wh/kg) [6], which makes Li-ion batteries very attractive to mobile applications with huge demand. It has caused extensive research in the field and subsequent rapid decline in price recently [5]. However, despite this significant decrease, Li-ion still remains expensive technology $[7,11]$. Other drawbacks of Li-ion batteries are their short discharge duration, energy capacity degradation [8], relatively short lifetime and low number of cycles [10]. That puts constraints to the charge / discharge cycles planning in a long term.

Flow batteries possess longer lifetime in terms both years and cycles [5]; they do not degrade as quickly as Li-ion [8]. Therefore, their limitations for annual number of cycles are noticeably less. Because of the feature of external tanks, flow batteries are potential to MWhs capacities. The drawback of flow batteries is their low energy and power density. Hence, their niche is applications with long duration and without mass or space constraints - it is stationary bulk energy storage [13].

In this paper, we estimate the flow batteries life cycle costs (LCC) in Section II, and then examine economic feasibility of the technology in three potential business cases for a bulk energy storage: price arbitrage in physical energy markets, bidding in reserve energy markets and RES balancing in isolated islanded systems (Section III). The results are presented in Section IV, followed by conclusions in Section V.

\section{COST ANALYSIS OF FLOW BATTERIES}

The majority of reports evaluate EES technologies using Levelized cost of storage (LCOS), i.e. how much a storage adds to the price of electricity [12]. Meanwhile, Life cycle costs (LCC) analysis allows assessing the economic feasibility of employing a system from owner's point of view, considering the procurement and ownership costs discounted on a yearly basis over the lifetime [15].

In this work, LCC calculation is done according to the method by Zakeri and Syri [9]; interest rate is 6\%; annual inflation rate $2 \%$ and exchange rate: $1 \$=0.81 €$. The updated 
data on cost items and technical characteristics for Vanadium redox batteries (VRB), Zinc-Bromine redox batteries (ZBRF) and Zinc-air batteries ( $\mathrm{Zn}$-air) are presented in Tables I and II, respectively. Information for Li-ion and PHES is included for comparison.

\section{TABLE I. LIFE CYCLE COST ITEMS OF SELECTED STORAGE TECHNOLOGIES [8, 10-11, 13-14]}

\begin{tabular}{|c|c|c|c|c|c|c|}
\hline \multirow[b]{2}{*}{$\begin{array}{c}\text { EES } \\
\text { system }\end{array}$} & \multicolumn{5}{|c|}{ Cost item } & \multirow[b]{2}{*}{$\begin{array}{c}\text { LCC } \\
(€ / \mathbf{k W}- \\
\mathbf{y r})\end{array}$} \\
\hline & $\begin{array}{c}P C S^{a} \\
(\epsilon / k W)\end{array}$ & $\begin{array}{c}\text { storage } \\
(\epsilon / \boldsymbol{k} W h)\end{array}$ & $\begin{array}{c}\text { fixed } \\
\text { O\&M } \\
(€ / k W- \\
y r)\end{array}$ & $\begin{array}{c}V O M^{c} \\
(\boldsymbol{\epsilon} / \boldsymbol{k} \boldsymbol{W h})\end{array}$ & $\begin{array}{c}\text { replace- } \\
\text { ment } \\
(\boldsymbol{\epsilon} / \mathrm{k} W h)\end{array}$ & \\
\hline VRB & 474 & 476 & 8.25 & 0.001 & 134 & 258 \\
\hline ZBRF & 506 & 351 & 4.3 & 0.0006 & 168 & 261 \\
\hline Zn-air & 310 & 242 & 7.5 & 0.002 & 122 & 187 \\
\hline Li-ion & 463 & 880 & 6.9 & 0.0021 & 370 & 540 \\
\hline PHES & 513 & 68 & 4.6 & 0.0002 & 0 & 108 \\
\hline
\end{tabular}

c. Variable operation \& maintenance costs

TABLE II. TECHNICAL CHARACTERISTICS OF THE SELECTED STORAGE TECHNOLOGIES RELEVANT TO LCC ANALYSIS [6, 8-14]

\begin{tabular}{|c|c|c|c|c|}
\hline $\begin{array}{c}\text { EES } \\
\text { technology }\end{array}$ & $\begin{array}{c}\text { Discharge } \\
\text { time (h) }\end{array}$ & $\begin{array}{c}\text { Overall } \\
\text { efficiency }\end{array}$ & $\begin{array}{c}\text { Life-time, } \\
\text { yr (cycle) }\end{array}$ & $\begin{array}{c}\text { Replacement } \\
\text { time, year } \\
\text { (cycle) }\end{array}$ \\
\hline VRB & 10 & 0.72 & $\begin{array}{c}20 \\
(10000)\end{array}$ & $8(10000)$ \\
\hline ZBRF & $4-10$ & 0.7 & $\begin{array}{c}10 \\
(10000)\end{array}$ & $15(5500)$ \\
\hline Zn-air & $4-10$ & 0.7 & $10(5000)$ & \\
\hline Li-ion & $1.5-2$ & 0.9 & $10(4500)$ & $8(4500)$ \\
\hline PHES & 8 & 0.75 & $\begin{array}{c}50 \\
(20000)\end{array}$ & - \\
\hline
\end{tabular}

\section{FEASIBLE APPLICATIONS OF FLOW BATTERIES}

\section{A. Potential in the Day-ahead market in Finland}

The diurnal pattern of electricity prices to be lower at night and higher in peak periods at daytime suggests economic potential for a bulk storage in price arbitrage in day-ahead physical energy markets [16]. We will examine the feasibility of such application of a flow battery for the case of the Finnish price area in the NordPool day-ahead market Elspot.

The potential profit depends on the price differences, the number of charge / discharge hours and efficiency of the system. The maximum gain naturally happens when the margin between the prices at discharge hour $\left(\mathrm{P}_{\mathrm{dis}}\right)$ and charge hour $\left(\mathrm{P}_{\mathrm{ch}}\right)$ is the largest.

Equation (1) considers the maximized revenues for one full day [11]:

$$
P_{E E S}=\sum_{i=1}^{h}\left(P_{d i s, i}^{\max } \cdot \eta_{s y s}-P_{c h, i}^{\min }-C_{V O M}\right)
$$

with the condition

$$
P_{d i s, i}^{\max } \cdot \eta_{s y s}-P_{c h, i}^{\min }-C_{V O M}>0
$$

where $P_{d i s, i}^{\max }$ - price of electricity at discharge hour $i, P_{c h, i}^{\min }-$ price of electricity at charge hour $i, \eta_{\text {sys }}$ - battery system efficiency, $C_{V O M}$ - variable O\&M costs which is marginal cost of production, $\mathrm{h}$ - charge / discharge duration.

The sum of the profits in every day gives the amount of the annual revenues.

Based on the Elspot price data for 2013-2017 years [17], the estimation was performed for a sample $1 \mathrm{MW}$ flow battery with $72 \%$ efficiency with maximum charge/discharge time $h$ equal 4 and 8 hours. The values of potential revenues are presented on Fig. 1.

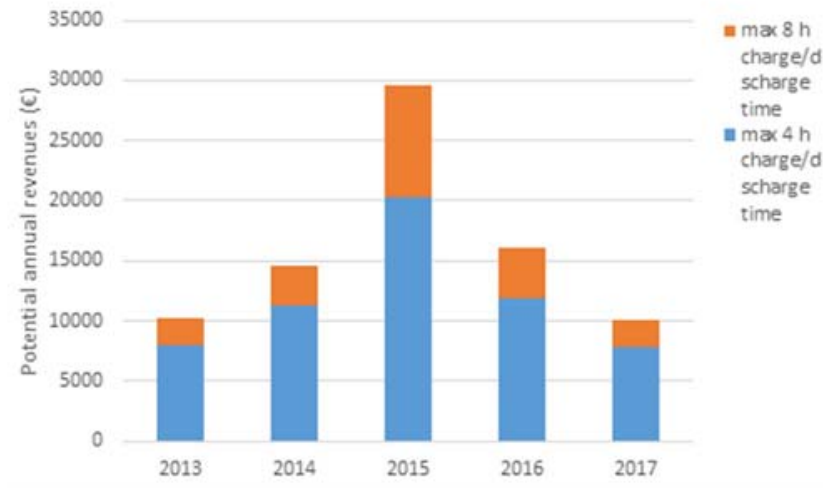

Figure 1. Potential annual revenues from $1 \mathrm{MW}$ flow battery in daily price arbitrage in the Finnish price area of the Day-ahead market

\section{B. Potential in the Finnish Reserve markets}

In order to keep the system frequency at $50 \mathrm{~Hz}$, national transmission operators (TSO) have to balance all deviations that appear between generation and consumption. For this purpose, they purchase required reserve capacity in the dedicated competitive markets. Reserve providers receive the payment if their bid is accepted [18]. BESS are capable to offer their capacity and participate in this trade, as well [11].

Among all levels of the Finnish reserve markets, Frequency containment reserves for normal operation (FCR-N) hourly market is argued to offer the best profitability perspectives for an energy storage [19].

Considering that all the bids were accepted and based on the Finnish TSO Fingrid data, the potential annual $1 \mathrm{MW}$ BESS revenues from participating in the Finnish FCR-N hourly market are presented on Fig. 2 [20]. 


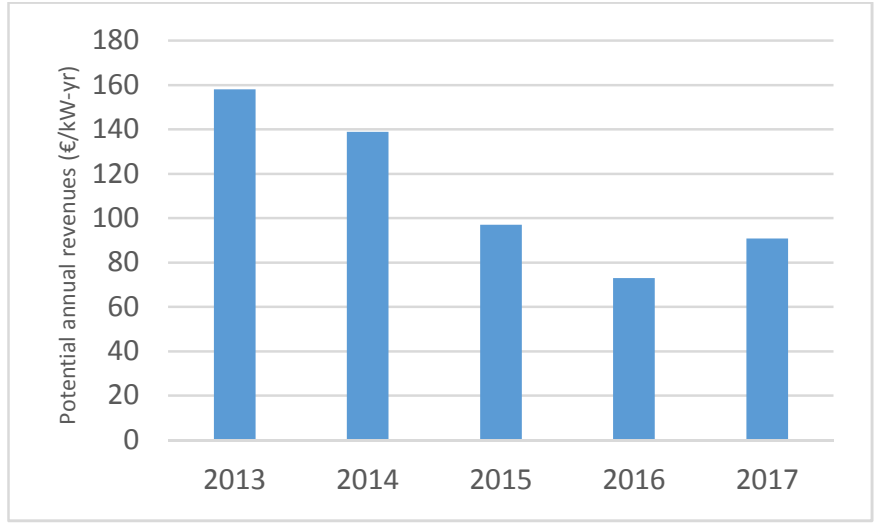

Figure 2. Potential revenues from $1 \mathrm{MW}$ flow battery in the Finnish reserve markets.

\section{RES balancing on islands}

The implementation of batteries allows greater use of RES and thus less thermal plants employment. Consequent savings from the reduced fuel expenses could be considered as the potential source of monetary benefits. This effect is more prominent in the remote island systems due to extra logistical costs and challenges in fuel delivery.

For the case studies, we have chosen two islands that had announced their intention for implementing high shares of RES into their power systems - the Faroe Islands and the island of Graciosa in the Azores archipelago.

\section{1) The Faroe Islands}

The Faroe Islands is an isolated archipelago of 18 islands in the northern Atlantic Ocean. It is a self-governing country within the Kingdom of Denmark with population of 50000 [21]. Electricity generation and transmission is conducted by the vertical utility called SEV [22]. The installed generation capacity is $105 \mathrm{MW}$. The electricity production was $317 \mathrm{GWh}$ in 2016 and $334 \mathrm{GWh}$ in 2017. $50 \%$ of the generation was derived from RES (hydro-power $33.5 \%$ and wind energy $16.4 \%$ ), the rest $50 \%$ was produced by heavy oil thermal plants $[22,24]$.

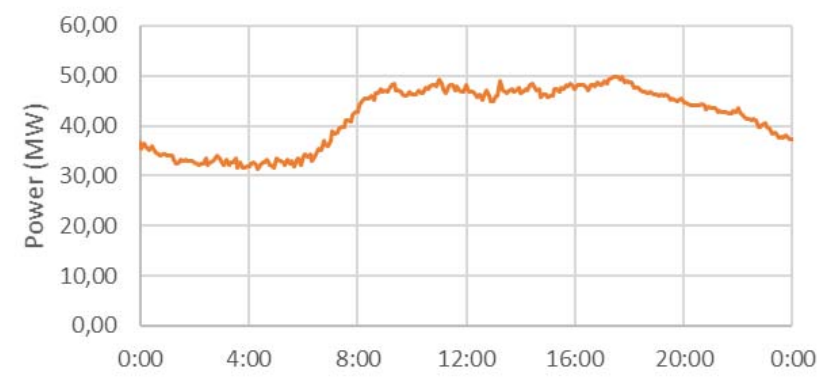

Figure 3. Daily demand curve of the Faroe Islands on 13.12.2017. (data from [23])

The potential for wind energy is large on the Faroe Islands, and SEV has announced the target to make its generation $100 \%$ renewable by 2030 [24]. Due to the high instability of wind generation, achieving the aim is impossible without wide introduction of energy storages for mitigating the variable output. In fact, in $2016 \mathrm{SEV}$ installed their first $2.3 \mathrm{MW} / 0.7$ MWh Li-ion battery that allowed to decrease wind curtailment and increase the wind farm utilization by $10 \%$ [25].

\section{2) Graciosa.}

Graciosa Island (4.6 MW and 14.2 GWh production in 2016) is part of the Azores Islands (Portugal) in the central Atlantic Ocean. All local electricity is produced by diesel generators currently. Meanwhile, the local energy utility EDA has the project to increase the RES share up to $65 \%$ by constructing 4.5 MW wind park and 1 MW solar farm combined with an EES $[26,27]$. The load curve for the island was obtained by using the Portuguese pattern and scaling to the Graciosa values [28].

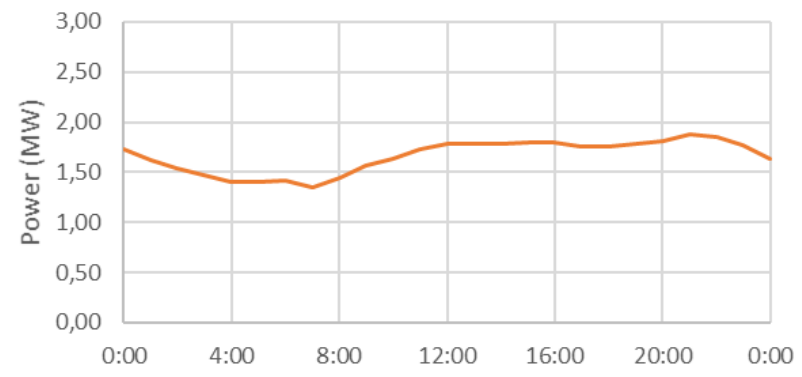

Figure 4. Daily demand curve of Graciosa Island on 13.08.2017.

\section{3) Simulation}

The simulation of islanded power systems was performed using HOMER (Hybrid Optimization of Multiple Energy Resources) software [29]. First, we built the models of the current state of the island systems (the Faroe Islands - 54 MW of oil thermal plants, $35 \mathrm{MW}$ hydro power and $16 \mathrm{MW}$ wind park (18 Enercon E44 900 turbines) [24]; Graciosa - 100\% diesel generators [26]). Then the models of the targeted states were accomplished $(100 \%$ RES in the Faroe Islands and the diminished to 35\% diesel generation in Graciosa). The benefits of flow batteries employment were evaluated through the comparison of the both states and the reduction in the consumed fuel in particular.

The values of wind and solar generation were obtained from www.renewables.ninja service [30].

\section{RESULTS}

\section{A. Economic feasibility in the Day-ahead market}

In this section, the economic feasibility of flow batteries in the Finnish price area of the Day-ahead Elspot market was examined for the period 2013-2017. The results are presented in Table III. As can be seen, the yearly benefits cover mere 4$8 \%$ of flow batteries operation costs. Therefore, flow batteries employment in the daily price arbitrage is far from profitable. 
TABLE III. YEARLY AVERAGED BENEFITS IN ELSPOT DAYAHEAD MARKET FOR THE PERIOD 2013-2017 AND ANNUAL COSTS FOR FLOW BATTARIES

\begin{tabular}{|c|c|c|c|c|c|}
\hline \multirow[t]{2}{*}{$\begin{array}{c}\text { Flow } \\
\text { battery }\end{array}$} & \multirow[t]{2}{*}{$\begin{array}{l}\text { Cost } \\
(€ / \mathbf{k W}- \\
\text { yr) }\end{array}$} & \multicolumn{2}{|c|}{$\begin{array}{c}\max 4 \mathrm{~h} \\
\text { charge/discharge } \\
\text { time }\end{array}$} & \multicolumn{2}{|c|}{$\begin{array}{c}\text { max } 8 \text { h } \\
\text { charge/discharge } \\
\text { time }\end{array}$} \\
\hline & & $\begin{array}{c}\text { Average } \\
\text { benefit } \\
(\epsilon / k W-y r)\end{array}$ & $\begin{array}{c}\text { benefit- } \\
\text { to-cost } \\
\text { ratio }\end{array}$ & $\begin{array}{c}\text { Average } \\
\text { benefit } \\
(\epsilon / k W-y r)\end{array}$ & $\begin{array}{c}\text { benefit- } \\
\text { to-cost } \\
\text { ratio }\end{array}$ \\
\hline $\begin{array}{l}\text { VRB, } \\
\text { ZBRF }\end{array}$ & 260 & \multirow[t]{2}{*}{11.83} & $4.6 \%$ & \multirow[t]{2}{*}{16.11} & $6.2 \%$ \\
\hline Zn-air & 187 & & $6.3 \%$ & & $8.6 \%$ \\
\hline
\end{tabular}

\section{B. Economic feasibility in the Finnish reserve markets}

The same examination was performed for the potential flow batteries application in the Finnish reserve markets. It should be noted that we considered ideal and in reality mostly unlikely case of all bids being accepted. Nonetheless, the annual revenues still could cover only $40-60 \%$ of the costs of flow batteries operation. Therefore, the flow batteries employment in the Finnish balancing market is not economically profitable even in ideal conditions.

The results are presented in Table IV.

TABLE IV. YEARLY AVERAGED BENEFITS IN THE FINNISH RESERVE MARKETS FOR THE PERIOD 2013-2017 AND ANNUAL COSTS FOR FLOW BATTARIES

\begin{tabular}{|c|c|c|c|}
\hline $\begin{array}{c}\text { Flow } \\
\text { battery }\end{array}$ & $\begin{array}{c}\text { Cost } \\
(\boldsymbol{\epsilon} / \mathbf{k W}-\mathbf{y r})\end{array}$ & $\begin{array}{c}\text { Average } \\
\text { benefit } \\
(\boldsymbol{\epsilon} / \mathbf{k W}-\mathbf{y r})\end{array}$ & $\begin{array}{c}\text { benefit-to- } \\
\text { cost ratio }\end{array}$ \\
\cline { 1 - 1 } $\begin{array}{c}\text { VRB, } \\
\text { ZBRF }\end{array}$ & 260 & \multirow{2}{*}{111.6} & $43 \%$ \\
\cline { 1 - 1 } Zn-air & 187 & & $60 \%$ \\
\hline
\end{tabular}

\section{Economic feasibility in the island electricity grids}

\section{1) The Faroe Islands}

According to the simulation, $50 \mathrm{MW}$ EES is required to provide the reliable supply for the Faroe Islands in case of $100 \%$ RES generation. Therefore, the annual LCC of flow battery systems would comprise $13 \mathrm{mln} € / \mathrm{yr}$ for $\mathrm{VRB}$ and ZBRF or $9.3 \mathrm{mln} € / \mathrm{yr}$ for Zn-air.

According to the SEV annual reports [24], the heavy oil prices have varied significantly for the company in recent years. Based on these values and assuming 365 cycles per year, we calculated the potential costs and benefits of flow batteries operation on the Faroe Islands. Table V presents the results. As can be seen, the economic feasibility of BESS operation noticeably depends on the fuel price. Fig. 5 shows the dependence of flow batteries benefit-to-cost ratio on the fuel price.
TABLE V. FEASIBILITY OF FLOW BATTERIES EMPLOYMENT ON THE FAROE ISLANDS WITH $100 \%$ RES GENERATION

\begin{tabular}{|c|c|c|c|c|c|}
\hline \multirow[b]{2}{*}{ year } & \multirow{2}{*}{$\begin{array}{c}\text { Total } \\
\text { fuel } \\
\text { expenses } \\
\text { (mln } € \text { ) }\end{array}$} & \multicolumn{2}{|c|}{ VRB, ZBRF } & \multicolumn{2}{|c|}{ Zn-air } \\
\hline & & $\begin{array}{c}L C C \\
(\epsilon / k W- \\
y r)\end{array}$ & $\begin{array}{c}\text { benefit-to- } \\
\text { cost ratio }\end{array}$ & $\begin{array}{c}L C C \\
(\epsilon / k W- \\
y r)\end{array}$ & $\begin{array}{c}\text { benefit-to- } \\
\text { cost ratio }\end{array}$ \\
\hline 2013 & 22.48 & \multirow{5}{*}{260} & 1.73 & \multirow{5}{*}{187} & 2.4 \\
\hline 2014 & 18.97 & & 1.46 & & 2.03 \\
\hline 2015 & 11.52 & & 0.89 & & 1.23 \\
\hline 2016 & 6.82 & & 0.52 & & 0.73 \\
\hline 2017 & 11.36 & & 0.87 & & 1.21 \\
\hline
\end{tabular}

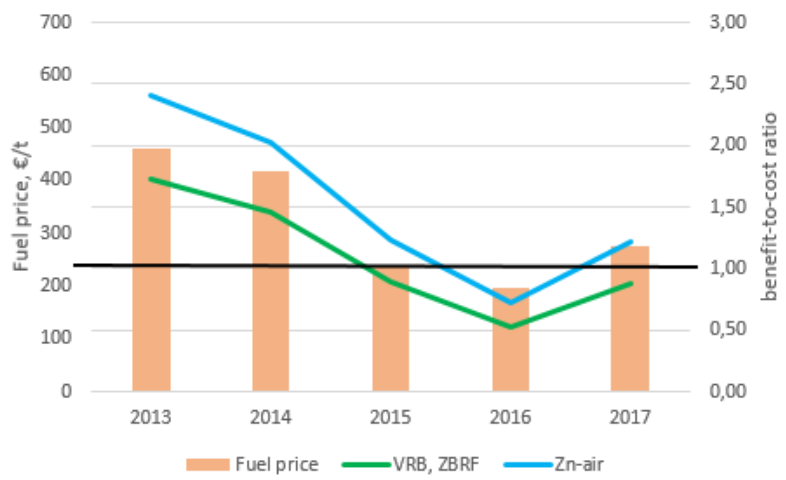

Figure 5. Dependence of flow batteries benefit-to-cost ratio on the fuel prices on the Faroe Islands.

\section{2) Graciosa}

HOMER simulations show that the diesel consumption decreases from $3.6 \mathrm{mln}$ 1/year in the current conditions of $100 \%$ thermal generation to $1.2 \mathrm{mln} 1 /$ year in the targeted situation of $65 \%$ RES penetration and 4 MW EES.

According to the EDA annual reports [31], the diesel prices have highly varied throughout the recent years. Fig. 6 represents the potential monetary savings from fuel consumption reduce by $2.4 \mathrm{mln}$ liters per year in comparison with the costs of employing flow batteries alone and combined with the RES costs. Levelized costs of 4.5 MW wind turbines are estimated $685000 € / \mathrm{yr}$ (assuming $1200 € / \mathrm{kW}$ capital cost, $30 € / \mathrm{kW}$-yr O\&M costs, lifetime 20 years, $\mathrm{i}=8 \%$ [32]) and $110000 € / y r$ for $1 \mathrm{MW}$ solar farm $(1100 € / \mathrm{kW}$ capital cost, 10 $€ / \mathrm{kW}$-yr O\&M costs, lifetime 30 years, $\mathrm{i}=8 \%$ [32]).

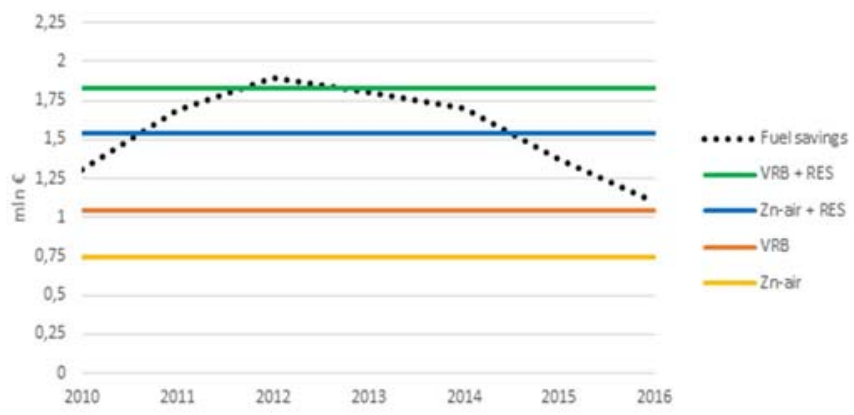

Figure 6. Potential fuel saving and costs of employing $4 \mathrm{MW}$ flow battery, along with 4.5 MW wind park and $1 \mathrm{MW}$ solar farm, on Graciosa. 
As can be seen in the graph, the flow batteries employment in the Graciosa power system is a viable option.

\section{CONCLUSIONS}

The analyses performed in this contribution show that BESS applications are currently far from profitable operation in the Nordic market. In the most promising market, i.e. hourly FCR-N market, flow batteries were able to collect $43-60 \%$ of their costs during the analysis period 2013-2017. In isolated islanded systems, the profitability can be significantly better due to the high costs of the most common generation fuels, heavy oil and diesel. The analysed here cases showed that a system with the high RES penetration level and BESS would be a competitive option already today. Especially in small islands like Graciosa, flow batteries would be a viable alternative due to their long lifetime and ability to run a large number of annual cycles. However, actual profitability greatly depends on the volatile fuel prices.

\section{ACKNOWLEDGMENT}

This work was performed within HEBSTO project and financially supported by Aalto University Energy Platform.

\section{REFERENCES}

[1] O. S. Burheim, Engineering energy storage, Academic Press, 2017, p.1.

[2] Nord Pool. Price formation, [online]. Available: https://www.nordpoolgroup.com/the-power-market/Day-ahead-market/Priceformation [accessed 11 Jan 2018].

[3] DOE Global Energy Storage Database. United States Department of Energy. Office of Electricity \& Energy Reliability [online]. Available: http://www.energystorageexchange.org/projects [accessed 10 Apr 2018]

[4] R. Higgins, Energy storage. Fundamentals, materials and applications. Springer, 2016.

[5] Electricity storage and renewables: costs and markets to 2030. IRENA (International Renewable Energy Agency), 2017 [online]. Available: http://www.irena.org/publications/2017/Oct/Electricity-storage-andrenewables-costs-and-markets [accessed 15 Jan 2018]

[6] M. Aneke and M. Wang, Energy storage technologies and real life applications - A state of the art review. Applied Energy. Vol 179, pp. 350-377, 2016.

[7] D. Parra et al, An interdisciplinary review of energy storage for communities: Challenges and perspectives, Renewable and Sustainable Energy Reviews, Vol. 79, pp 730-749, 2017.

[8] M. Kleinberg, Battery energy storage study for the 2017 IRP, PacifiCorp, 2017.

[9] B. Zakeri and S. Syri, Economy of Electricity Storage in the Nordic Electricity Market: The Case for Finland, Proceedings of 11th International Conference on the European Energy Market (EEM), Krakow, 2014.

[10] B. Zakeri and S. Syri, Electrical energy storage systems: A comparative life cycle cost analysis. Renewable and sustainable energy reviews, vol. 42, pp 569-596, 2015

[11] B. Zakeri, S. Syri and F. Wagner, Economics of energy storage in the German electricity and reserve markets, Proceedings of 14th International Conference on the European Energy Market (EEM), Dresden, 2017.
[12] V.Jülich, Comparison of electricity storage options using levelized cost of storage (LCOS) method, Applied Energy, vol. 183, pp 1594-1606, 2016.

[13] Lazard's Levelized Cost of Storage Analysis - Version 3.0 (2017). [Online] Available: www.lazard.com/media/450338/lazard-levelized-cost-ofstorage-version-30.pdf

[14] Lazard's Levelized Cost of Storage Analysis - Version 2.0 (2016). [Online] Available: https://www.lazard.com/media/438042/lazard-levelizedcost-of-storage-v20.pdf

[15] B.S. Dhillon, Life cycle costing for engineers, CRC Press, 2010.

[16] M. Waterson, The characteristics of electricity storage, renewables and markets. Energy policy, 104, pp 466-473, 2017.

[17] Nordpool. Elspot prices [online]. Available: https://www.nordpoolgroup.com/Market-data1 [accessed 28 Feb 2018].

[18] Fingrid. Electricity market. Reserves and balancing power, [online]. Available: https://www.fingrid.fi/en/electricity-market/reserves_and balancing/\#reserve-obligations-and-procurement-sources [accessed 11 Feb 2018]

[19] N. Saulny. Operation and profitability of batteries in electricity reserve markets. Aalto University. Master's Thesis. 2017.

[20] Fingrid. Frequency Containment Reserves (FCR-N, FCR-D), transactions in the hourly and yearly markets, [online]. Available: https://www.fingrid.fi/en/electricity-market/reserves and balancing/reservemarket-information/frequency-controlled-disturbance-reserve [accessed 11 Feb 2018]

[21] The official gateway to the Faroe Islands. [online]. Available: https://www.faroeislands.fo/ [accessed 12 Dec 2017].

[22] SEV official site [online]. Available: http://www.sev.fo_[accessed 12 Dec 2017].

[23] SEV official site. Current production, [online]. Available: https://w3.sev.fo/framleidsla/ [accessed 13 Dec 2017].

[24] Electricity company SEV. Annual Report and Annual Accounts 2016 Tangible plan for the green course. [online] Available:

http://www.sev.fo/Admin/Public/DWSDownload.aspx?File=\%2fFiles\%2fFil er\%2fUm_sev\%2ffradgreidingar\%2fSEV+Production+2016.pdf

[25] T. Nielsen. Managing massive wind integration in islands with battery storage. Webinar on storage for island energy systems by EURELECTRIC on 8 Sept 2017.

[26] EDA. Electricidade dos Açores - Procura e Oferta de Energia Elétrica, dezembro 2016. [online] Available:

http://www.eda.pt/Mediateca/Publicacoes/Producao/ProducaoConsumo/POE E\%20dezembro\%202016.pdf

[27] P. Stenzel et al. Renewable energies for Graciosa Island, Azores - Life Cycle Assessment of electricity generation. Proceedings of 11th International Renewable Energy Storage Conference, IRES, Dusseldorf, 2017.

[28] ENSTO-E. Power Statistics. [online] Available: https://www.entsoe.eu/data/power-stats/hourly load/

[29] HOMER Energy, HOMER Pro 3.11 User manual, November 2017 [online]. Available: https://www.homerenergy.com

[30] Renewables.ninja. [online]. Available: www.renewables.ninja

[31] EDA. Relatório e contas 2011-2016. [online] Available: http://www.eda.pt/Mediateca/Publicacoes/Paginas/Relatorios.aspx

[32] Lazard's levelized cost of energy analysis - Version 11.0 (2017) [Online] Available: https://www.lazard.com/media/450337/lazard-levelized-cost-ofenergy-version-110.pdf 